\title{
Między wysoką i niską kulturą, czyli batalia o trywialność
}

\author{
Anna Gawarecka, Margines i centrum. Obecność form kultury \\ popularnej w literaturze czeskiej dwudziestolecia międzywojennego, \\ Wydawnictwo Naukowe UAM, Poznań 2011, ss. 398
}

\begin{abstract}
Nad recenzją inspirującej książki Anny Gawareckiej Margines i centrum. Obecność form kultury popularnej w literaturze czeskiej dwudziestolecia międzywojennego zastanawiałam się, gdy w zasypanej śniegiem Warszawie słupy ogłoszeniowe - przynajmniej w okolicach uniwersytetu wciąż były oblepione plakatami Sprawy Makropulos. Tegoroczna, lutowa premiera opery Leoša Janačka, której libretto oparto na sztuce Karla Čapka Věc Makropulos, stała się wydarzeniem sezonu, bo po raz pierwszy to dzieło wybitnego czeskiego kompozytora prezentowano w Polsce, a podążała za nim sława sukcesu, jaki odniósł jego reżyser Christoph Marthaler podczas festiwalu w Salzburgu w 2011 roku.

Nie przypadkiem o tym wspominam i nawet nie dlatego tylko, że Čapek jest ważnym bohaterem pracy Anny Gawareckiej. Prasowe komentarze towarzyszące wystawieniu dzieła na deskach Opery Narodowej wprowadzają nas in medias res problemu, któremu autorka poświęciła pracę. Interpretacja Marthalera, kładącego nacisk na koszt idei wiecznej młodości (sztandarowego produktu kulturowego także naszych czasów), sprowokowała wiele wypowiedzi, jakich nie powstydziłby się żaden tabloid. Największe polskie dzienniki wabiły czytelnika krzykliwą obietnicą „Młodości 300-latki”, aby go potem, już z powaga, informować o muzyce Janačka, zapóźnionego romantyka, a jednocześnie współtwórcy czeskiego muzycznego modernizmu. Znaleźliśmy się więc „w centrum” tego, o czym wnikliwie pisze Anna Gawarecka, rozważając różne przypadki artystycznego wykorzystywania niskich, brukowych form literackich, czego celem ostatecznym nie jest zadowolenie prostych gustów niewyrobionego czytel-
\end{abstract}


nika. On bowiem ma zostać „otworzony” na treści, które - zaproponowane w formie trudniejszej - najprawdopodobniej ominąłby jako obce i nieciekawe. Autorka, pokazując, jak zaciera się granica tradycyjnego podziału na kulturę wysoką i niską, w jaki sposób ta ostatnia dostarcza form i schematów przechwytywanych i przetwarzanych przez tę pierwszą, podejmuje się analizy zjawiska, ważnego, które stanowi charakterystyczną cechę kultury współczesnej. Tym ważniejsze jest ono dla kultury czeskiej, że w istotnym dla jej rozkwitu okresie dwudziestolecia międzywojennego, zjawiskiem o pierwszorzędnej wadze było właśnie pytanie o możliwości wykorzystania tego, co niskie, dla stworzenia „odświeżonych” projektów kulturowych i zdobycia „dla kultury” publiczności dotąd lekceważonej.

W czeskiej literaturze sensacyjna lub romansowa kapsuła nosiła treści dużo bardziej złożone, niż zakładały standardy kultury umasowionej, a działo się to na skalę, która czyni ten fenomen niemożliwym do przeoczenia. Dobrze więc, że Anna Gawarecka zajęła się tym zagadnieniem, tworząc zarazem własną formułę jego interpretacji.

Wskazuje na to konstrukcja książki i dobór nazwisk oraz przykładów literackich, które dostarczyły materiału do prezentacji problemu. O ile bowiem ,gry z tandetą" są znanym elementem twórczości Čapka, a autorka w tym zakresie dysponowała sporą literaturą przedmiotu, o tyle popatrzenie z interesującej ją perspektywy na twórczość Ladislava Klímy to już jej własna inwencja. Początkowo może ona zaskakiwać. Jak pisze autorka, twórczość tego pisarza była dotąd obszarem eksploracji przede wszystkim filozofów i pod tym też kątem ją odczytywano. Wprowadzenie w te „wysokie progi" treści i form dalekich od wyśrubowanego poziomu artystycznej i intelektualnej hierarchii pokazuje, jak istotną funkcję pełnią te ,niskie" czynniki w koncepcji kultury Klímy. I choć w szczegółach można z tym polemizować, trudno nie przyznać, że takie ujęcie wyjaśnia kilka kwestii mało klarownych w świetle dotychczasowych interpretacji. Przykładowo, zawsze zastanawiało mnie utrwalone przekonanie, że Klíma był nietzscheanistą. Bez watpienia wiele czerpał od niemieckiego filozofa, ale czy on i jego „wola mocy” to ,święte świętych” w świecie czeskiego prześmiewcy i prowokatora? Jeśli tak, to dlaczego Helga, bohaterka Cierpień księcia Sternenhocha, parzy się z dzikimi zwierzętami i jednocześnie daje im filozoficzne wykłady, odbywa podróże na księżyc i na dno oceanu, stając się jakby ucieleśnionym groteskowym przetworzeniem nietzscheań- 
skiego triumfu woli, poddania jej zarówno świata kultury, jak i natury? Zderzanie sprzecznych kulturowych dyskursów, dokonywane przez Klímę, przedstawianie dewaluacji i wyczerpania tego, co wysokie i poważne, stanowią nieusuwalny element jego pisarstwa, tak samo jak jego histeryczna wręcz potrzeba, by jakiś sens istniał. Nie można więc celnie mówić o tej zwariowanej spuściźnie, nie uwzględniając, w jaki sposób powaga żyje obok niepowagi, afirmacja obok negacji, patos obok groteski. Nie wykluczają się one, lecz koegzystuja, wprawdzie w sporze i w zwarciu, ale koegzystuja, podobnie do tego, jak w kulturowych koncepcjach Michela Foucaulta rozum wykrawał sobie obszar oblewany natrętną falą nierozumu. Jestem wdzięczna autorce za ten rozdział, choć często z konkretnymi jej interpretacjami chętnie bym podyskutowała. Doceniam jednak jej wysiłek choćby dlatego, że literatura przedmiotu, do której mogła się odwołać, pozostawała nadzwyczaj skromna. W analizach autorki pracy Klíma występuje jako główne źródło objaśniające Klímę, bowiem to w korespondencji w innych komentarzach pisarza Anna Gawarecka znajduje potwierdzenie swych tez. To dowodzi, na jak słabo zbadane pola zawiodła ją pogoń za czeskimi „grami z tandetą".

Oryginalny jest również rozdział poświęcony Josefowi Čapkowi. Dla historyków literatury istnieje on głównie jako brat wielkiego Karla, współautor ich wczesnych utworów. Własna twórczość Josefa omawiana jest zwykle pospiesznie, a sam artysta wydaje się ceniony głównie jako malarz, nie pisarz. Mikrostudium autorki burzy te ustalone nawyki. I słusznie, tym bardziej że przy okazji wprowadza czytelnika w szerszy kontekst Josefowych koncepcji kultury.

Książka Anny Gawareckiej została skonstruowana w taki sposób, aby „studia przypadków” (obok wymienionych już Čapków i Klímy występuje jeszcze Ivan Olbracht) połączyć z szeroką perspektywą historyczno-literacką, teoretyczną i kulturową. $\mathrm{W}$ pierwszym rozdziale zostaje ukazana droga odkrywania użyteczności form popularnych, w której istotnym etapem było czeskie doświadczenie odrodzeniowe, a punktem dojścia batalia o rolę form tandetnych i jarmarcznych wyrażona w dyskusjach i manifestach międzywojnia. Prezentacja materiału rekapituluje i wiedzę dość dobrze znaną (program poetyzmu, założenia grupy Devětsil), i mniej upowszechnione aspekty sporów na temat „literatury brukowej”. Autorka w ciekawy sposób przedstawiła zmiany w podejściu do literatury popular- 
nej, zachodzące między latami dwudziestymi a trzydziestymi XX wieku, z kulminacją na przełomie lat trzydziestych i czterdziestych tegoż wieku. Tak powstał interpretacyjny model, w którym możemy umieszczać poszczególne elementy i fazy dyskusji: przykładowo kontrowersje na temat rodowodu pisarstwa trywialnego (Vachal a Čapek) czy dynamikę podejścia do literatury popularnej (Čapek a Soldan). Wykorzystana bibliografia, uwzględnienie prasy tego okresu, daje poczucie solidności prezentowanego obrazu.

Jeśli czegoś mi zabrakło to może obecnej w tle rozważań pamięci o tym, że w tym czasie czeska kultura chłonęła także i przetwarzała inspiracje europejskiej awangardy, a ci, którzy jak Čapek byli rzecznikami nieekskluzywnego modelu kultury i z pełną świadomością posługiwali się formami „niskimi”, pełnili też funkcję przewodników w świecie awangardowych odkryć. Podkreślam to, bo czytając książkę, miałam niejasne wrażenie, że „batalia o trywialność” jakby nadto odłączyła się od innych ówczesnych „batalii”, mających ostatecznie wspólny cel - modernizację kultury i odbiorcy. Niemniej jednak ówczesne eksperymenty z literaturą popularną stały się organiczną cechą czeskiego piśmiennictwa, kontynuowaną po wojnie przez tak wybitnych pisarzy, jak Josef Škvorecký czy Ladislav Fuks.

W rozdziale drugim autorka zajęła się zjawiskami parodii i pastiszu, $\mathrm{w}$ tej perspektywie umieszczając rehabilitację powieści sensacyjnych. Dzięki obu perspektywicznym ujęciom w książce wystąpiło wielu czeskich pisarzy, u których autorka śledzi wpływy kultury popularnej, a są to najważniejsze postaci czeskiej literatury okresu międzywojnia (Nezval, Vančura, Polaček, Voskowec i Werich, Bass, Vachal). Każda z tych osób to inny projekt ,gry z tandetą".

Rozdział trzeci to wspomniane „studia przypadków”, a rozważania zamyka prezentacja literatury popularnej już nie jako rezerwuaru poczytnych form i gatunków, lecz tematów, które rozpalały wyobraźnię masowego odbiorcy, a zarazem stawały się przedmiotem „obróbki” pisarzy, którzy chcieli nimi grać, a nie tylko je odtwarzać.

Samo omówienie konstrukcji książki uświadamia czytelnikowi z jak szeroko zakrojona pracą ma do czynienia. Jeśli dodamy do tego obszerne przypisy, to nie ma wątpliwości, że otrzymaliśmy rozprawę erudycyjna, prowokującą do myślenia. I do polemik, co uważam za atut. Moja główna 
obiekcja dotyczyłaby pewnego zachwiania równowagi między tym, co lokalne, czeskie, co osadzone w konkretnym „tu i teraz”, a perspektywą uniwersalną, związaną z teoretyczną refleksją na temat kultury popularnej, zwłaszcza w czasach ponowoczesnych. Te dwa ujęcia Anna Gawarecka chciała pogodzić, ukazując międzywojenne eksperymenty czeskich pisarzy oraz polemiki krytyków na temat ,gier z tandetą" jako antycypację „dzisiejszych prób i metod operowania elementami popularnych paradygmatów” (s. 368). Posiłkując się pracami m.in. Barthes'a, Baudrillarda, Baumana, Bourdieu, Derridy i innych wybitnych współczesnych filozofów i krytyków literatury, przedstawiała czeską intronizację jarmarcznej kultury jako zapowiedź wyzwań sprowokowanych przez postmodernizm. Zastanawiam się, czy zanim jednym skokiem znaleźliśmy się w postmodernizmie, nie warto było uwzględnić, choćby w skromnym zakresie, perspektywy modernistycznego przełomu. W wielu zakresach objaśniał on zjawisko interesujące autorkę, pozostawał w większej zgodności czasowej z materiałem niż interpretacje kulturowe głośne w naszych czasach i przywoływane w rozprawie.

To właściwie nawet nie zarzut, bo w tej roli przybierałby postać pytania, czemu książkę napisano tak, a nie inaczej - a każda w końcu jest wyborem określonej perspektywy i dramatycznych nierzadko decyzji, czego już nie sposób w niej umieścić. Myślę jednak, że modernizm rozumiany jako „seria kryzysów” - tożsamości jednostki, jednorodności dyskursu, klarowności gatunku; modernizm jako przełom demokratyzujący hierarchiczną wizję kultury, dopuszczający do głosu to, co dotąd krążyło po jej obrzeżach, nie powinien być $\mathrm{w}$ tej pracy wielkim nieobecnym. Podam jeden przykład związany z tak ważnym w książce Karlem Čapkiem. Choć zgadzam się, że wiele jego koncepcji kulturowych do „postmoderny” pasuje, to zarazem tym, w co wpasować go łatwiej, jest modernizm właśnie choć sam pisarz jako czytelnik gusta miał raczej konserwatywne i ,papieży modernizmu", w tym Jamesa Joyce'a, niezbyt cenił. Skoro jednak Anna Gawarecka poświęca sporo uwagi tak ważnemu u Čapka problemowi kulturowego wpływu, jego sceptycznej postawie wobec oryginalności, to aż prosi się, by przywołać tu nie tylko gry pisarza z ,jarmarkiem", ale też z najbardziej cenionymi autorami jego czasów. Čapek miał z tego powodu niemało kłopotów. Praska prapremiera Sprawy Makropulos przyniosła mu oskarżenia o artystyczną kradzież, której ofiarą miał paść Bernard Shaw 
i jego sztuka Powrót do Matuzalema. Dopiero sukces opery Janačka, w której tekst Čapka posłużył za libretto, przyćmił skandal. Takich przykładów można wskazać o wiele więcej i dotyczą one najpoważniejszych dzieł pisarza, także trylogii noetycznej. Korzystanie z form gotowych nie było więc strategią pisarską ograniczającą się do literatury popularnej, stanowiło szerszy projekt, w którym ,przesuwanie matryc” obejmowało i strywializowane kulturowe ,gotowce", i teksty oryginalne, mające autorów, dyskutowane w literackich salonach Europy.

Na koniec przykład, który pokazuje jak ważny problem poruszyła Anna Gawarecka. Tegorocznemu wystawieniu Sprawy Makropulos towarzyszyło wydanie - po raz pierwszy po polsku - sztuki Čapka Věc Makropulos. Tłumaczenie Jana Gondowicza miało jako ,akolitę" minikomiks autorstwa Macieja Sieńczyka, będący żartem z operowej konwencji. Czyż wysokie nie kłania się tu niskiemu? A gdy w roku 2009 Sprawa Makropulos w reżyserii Krzysztofa Warlikowskiego święciła triumf w paryskiej Opéra Bastille, któż harcował na scenie? - King Kong i Marilyn Monroe.

Danuta Sosnowska 